\title{
PROTEIN SYNTHESIS AND AMYLASE MESSENGER RNA CONTENT IN RAT PAROTID SALIVARY GLANDS AFTER TOTAL OR PARTIAL STIMULATION WITH ISOPROTERENOL
}

\author{
S. K. KIM, ${ }^{*}$ T. P. Jones and L. M. Cuzzort \\ Research Service, V.A. Medical Center and Department of Anatomy and Cell Biology, The University \\ of Michigan Medical School, Ann Arbor, MI 48105, U.S.A.
}

(Accepted 12 May 1989)

\begin{abstract}
Summary-The rate of synthesis of secretory proteins increases significantly in rat parotid glands after stimulated discharge of stored proteins. How any difference in the amount of secretory protein discharge affects the rate of subsequent protein synthesis, and whether this post-secretory synthesis is regulated at the level of messenger RNA, was now examined. One group of rats was stimulated to secrete $97 \%$ of stored secretory proteins by an intraperitoneal injection of isoproterenol. The other group received a much smaller dose to induce the discharge of about $40 \%$ of the proteins. Despite this difference in secretion, the subsequent rates of total protein synthesis, as well as of amylase, were increased to about the same extent. The amylase messenger RNA (mRNA) was identified and quantified by hybridization with a ${ }^{32}$ P-labelled amylase complementary DNA (cDNA) probe. The amylase mRNA in stimulated and unstimulated rats was of the same molecular size (Northern blot analyses). The amount of amylase mRNA, determined by dot blot analyses, were also increased in stimulated rats, although this increase was not as great as that in the rate of amylase protein synthesis. The implications of this discrepancy concern the possibility that the mechanism of regulation of secretory protein synthesis in parotid glands is at the translational level.
\end{abstract}

\section{INTRODUCTION}

In the parotid acinar cells, as in other exocrine glands, newly synthesized proteins are processed, packaged and stored for secretion (Palade, 1975; Castle, Jamieson and Palade, 1972). The stimulation of parotid glands by beta agonists, such as isoproterenol or epinephrine (Bdolah and Schramm, 1965; Babad et al., 1967; Amsterdam, Ohad and Schramm, 1969; Malamud, 1972; Lillie and Han, 1973), induces the release of stored secretory proteins from the acinar cells. The secretion is followed by an increased rate of synthesis of these proteins (Lillie and Han, 1973).

Studies of amino acid incorporation have indicated that the rate of post-secretory protein synthesis is increased compared to that in unstimulated glands. An increased rate of incorporation has been observed in parotid glands after secretion induced by feeding (Johnson and Sreebny, 1973; Sreebny, Johnson and Robinovitch, 1971), a secretogogue (Lillie and Han, 1973), or in vitro stimulation (Grand and Gross, 1970). After a single injection of isoproterenol ( $8 \mathrm{mg} / \mathrm{kg}$ body weight), which induces the discharge of $99 \%$ of stored secretory proteins within $2 \mathrm{~h}$ in rat parotid glands, the rates of incorporation of amino acids into acid-precipitable protein and amylase increase significantly, reaching the highest level at $6 \mathrm{~h}$. At this time, the rate of incorporation is about 2.5

*Address correspondence to: Dr S. K. Kim, Research Service, V.A. Medical Center, 2215 Fuller Road, Ann Arbor, MI 48105, U.S.A. times higher than in unstimulated glands (Lillie and Han, 1973).

Thus, it appears that secretion or some related cellular events affect the rate of subsequent protein synthesis. However, it is not known how the rate of post-secretory protein synthesis is regulated, or whether this regulation takes place at the level of transcription or translation. We have now examined how differences in amounts of secretion affect rates of subsequent protein synthesis, and whether the changes in rates of post-secretory synthesis accompany similar changes in levels of secretory protein messenger RNA.

\section{MATERIALS AND METHODS}

Rats

Male Sprague-Dawley rats weighing about $250 \mathrm{~g}$, were obtained from Harlan Sprague Dawley Inc. (Indianapolis, Ind., U.S.A.). They had no immunological titre for sialodacryoadenitis viruses, which are known to affect the structure and function of salivary glands (Jonas et al., 1969). The rats were housed in constant-temperature environment with $12 \mathrm{~h}$ cycles of day and night. Food was withheld for about $16 \mathrm{~h}$ before experiments but drinking water was available during this period. All experiments began at 8:00 a.m.

To induce discharge of stored proteins, rats were injected intraperitoneally with isoproterenol (Sigma, St. Louis, Mo., U.S.A.) dissolved in saline. A dose of $8 \mathrm{mg} / \mathrm{kg}$ body weight (Lillie and Han, 1973) was given 
to induce a near total discharge of stored proteins. Another group of rats was injected with $0.4 \mathrm{mg} / \mathrm{kg}$ body weight of isoproterenol, a dose which in preliminary experiments induced secretion of only about $50 \%$ of stored proteins; the control group was injected with saline only. The rats were then killed at various times by cardiac puncture after light methoxyflurane anaesthesia.

\section{Amylase activity assays}

Glandular amylase was extracted by homogenization in distilled water, and the differences in the enzyme levels among the groups were compared, based on the DNA content of the gland (Kim, 1981). The amylase level was determined by activity assays (Bernfeld, 1955), with starch as the substrate. The DNA content was determined by the diphenylamine method of Burton (1956).

\section{Radioactive amino acid incorporation studies}

For these, rats were injected with $1 \mu \mathrm{Ci} / g$ body weight of L-leucine, $4,5-{ }^{3} \mathrm{H}$, obtained from ICN Radiochemicals (Irvine, Calif., U.S.A.; $40 \mathrm{Ci} / \mathrm{mmol}$ ), and killed $30 \mathrm{~min}$ later. Parotid glands were removed, cleaned of connective tissue and fat, and homogenized in distilled water. The homogenate was divided into samples for various assays. Two samples of $1 \mathrm{ml}$ each were precipitated with $0.3 \mathrm{~N}$ perchloric acid to separate acid-soluble and -insoluble fractions (Kim et al., 1980, 1981; Kim and Arisumi, 1985). The amount of radioactivity incorporated into the acid-insoluble precipitate was determined by scintillation counting on a Beckman LS9800 spectrophotometer, after digestion in a commercially available tissue solubilizer (NCS; Amersham, Chicago, Ill., U.S.A.).

The incorporation values were corrected for differences in the size and specific radioactivity of the free leucine pool to insure that rates of leucine incorporation were not affected by changes in the precursor pool. The amino acid analysis was done by a Kratos analyser system (Interaction Co., Los Altos, Calif., U.S.A.), using the acid-soluble fractions of the gland (Kim and Arisumi, 1985). This system was equipped with a AA 511 cation exchange column and used $o$-phthaldehyde as the detection reagent. The amino acids were derivatized in a post-column reactor and detected fluorometrically with a Kratos FS 950 fluorometer, modified from Bohlen and Mellet (1979). One-minute fractions were collected in scintillation vials with a Gilson FC-100 fraction collector. Each fraction was mixed with Atomlight (New England Nuclear Products, Boston, Mass., U.S.A.) and radio activity measured in a LS9800 Beckman scintillation counter.

To compare rates of synthesis of secretory proteins, the incorporation of the label into amylase was measured; amylase was precipitated with glycogen (Loyter and Schramm, 1962) from samples of the gland homogenate for scintillation counting. Rates of $\left[{ }^{3} \mathrm{H}\right]$-leucine incorporation into the acid-insoluble fraction and the amylase were compared, based on the tissue DNA content.
Extraction of total cytoplasmic RNA from parotid glands

Total unfractionated RNA was extracted by the procedures of Chirgwin et al. (1979), which use guanidinium thiocyanate in the homogenizing medium to control RNase activity. RNA was precipitated with ethanol and acetic acid, dried, dissolved in sterile distilled water and kept in liquid nitrogen vapour, after division into samples. Frozen RNA was thawed and used once. Some RNA samples become degraded during extraction and precipitation. Therefore, each sample was separated into different sizes by electrophoresis on agarose gel containing ethidium bromide (Maniatis, Fritsch and Sanibrook, 1982). After this, only samples that showed two sharply separated ribosomal RNA bands were used for further studies. The ratio of $A_{260} / A_{280}$ of the RNA samples ranged from 2.09 to 2.14 . The DNA contamination was less than $1 \%$.

\section{Amylase cDNA probe preparation}

Escherichia coli bacteria (DHl strain), transformed with the $\mathrm{P}^{\mathrm{UC9}}$ plasmid containing a parotid amylase DNA sequence inserted at a Pstl site, were used as the source of amylase complementary DNA (cDNA). The plasmid DNA was isolated after culturing the bacteria in Luria-Bertani medium containing ampicillin $(50 \mu \mathrm{g} / \mathrm{ml}$; Maniatas $e t$ al., 1982). The bacterial culture was concentrated, lysed and treated with RNase. The supernatant was extracted twice with $15 \mathrm{ml}$ phenol-chloroform $(1: 1)$ mixture and once with chloroform only. Two volumes of absolute ethanol were added and the solution was left at $-20^{\circ} \mathrm{C}$ overnight to precipitate DNA. The next morning, the precipitate was centrifuged and treated with $0.4 \mathrm{ml} 4 \mathrm{M} \mathrm{NaCl}$ and $2 \mathrm{ml} 13 \%$ polyethylenglycol in ice water for $1 \mathrm{~h}$. After centrifugation, the pellet was washed in $70 \%$ ethanol, centrifuged again and dried under a $\mathrm{N}_{2}$ stream. The final pellet was dissolved in $10 \mathrm{mM}$ tris- $\mathrm{HCl}, 1 \mathrm{mM}$ EDTA and stored at $-20^{\circ} \mathrm{C}$ until used. The concentration if isolated DNA was determined by the absorbance at $260 \mathrm{~nm}$

Before oligolabelling, the plasmid was cut with the restriction enzyme Pstl to produce free amylase cDNA. The isolation of the amylase cDNA was not necessary because of its large size $(1.7 \mathrm{~kb})$ relative to that of the vector $(2.7 \mathrm{~kb})$. The cut cDNA was labelled with ${ }^{32} \mathrm{P}$, as described by Feinberg and Vogelstein (1983), using an oligolabelling kit (Pharmacia, Piscataway, N.J., U.S.A.) and $[\alpha$ $\left.{ }^{32} \mathrm{P}\right]$-deoxycytidine triphosphate $(3000 \mathrm{Ci} / \mathrm{mmol}$, Amersham). Unincorporated [ $\left.{ }^{32} \mathrm{P}\right]$-deoxycytidine triphosphate was separated from the labelled probe by gel filtration through a Sephadex G-50 column (Worthington Biochem. Corp., Freehold, N.J., U.S.A.). The specific activity of the probes ranged from 0.8 to $1.7 \times 10^{9}$ counts $/$ min per $\mu \mathrm{g} \mathrm{DNA}$ and the probe saturation was $400 \mathrm{ng}$ DNA $/ \mu \mathrm{g}$ RNA spotted. The probes were boiled to denature them before being added to the filters for hybridization.

\section{Hybridization}

RNA-bound filters (dot and Northern blots), placed in sealable plastic bags, were prehybridized at 
$42^{\circ} \mathrm{C}$ for $4 \mathrm{~h}$ (Maniatis et al., 1982); prehybridization solution was added at about $1 \mathrm{ml} / \mathrm{cm}^{2}$ of filter. The solution was then removed and hybridization solution (prehybridization solution + EDTA to $5 \mathrm{mM}$ ) was added to a final volume of $0.1 \mathrm{ml} / \mathrm{cm}^{2}$. The labelled probe was denatured by boiling in $10 \mathrm{mM}$ tris- $\mathrm{HCl}$ (pH 7.4), $1 \mathrm{mM}$ EDTA for $10 \mathrm{~min}$ and cooled to $42^{\circ} \mathrm{C}$. The denatured probe was added to the hybridization buffer and the blots were hybridized overnight (about $16 \mathrm{~h}$ ) at $42^{\circ} \mathrm{C}$. The next morning, the filters were removed from the sealed bags and washed at room temperature $\left(24^{\circ} \mathrm{C}\right)$ twice for $5 \mathrm{~min}$ each and twice for $10 \mathrm{~min}$ each in $2 \times \mathrm{SSC}$ $(0.3 \mathrm{M} \mathrm{NaCl}, 0.03 \mathrm{M}$ sodium citrate $) / 0.1 \%$ sodium dodecyl sulphate with about $2 \mathrm{ml}$ wash solution $/ \mathrm{cm}^{2}$. After this room temperature washing, the filters were washed in $0.1 \times \mathrm{SSC} / 0.1 \%$ sodium dodecyl sulphate at $50^{\circ} \mathrm{C}$ with shaking, once for $2 \mathrm{~h}\left(2 \mathrm{ml} / \mathrm{cm}^{2}\right)$, then once for $30 \mathrm{~min}\left(5 \mathrm{ml} / \mathrm{cm}^{2}\right)$. Washed filters were dried under a goose-neck lamp, plastic wrapped and exposed to film (Kodak XO-Matic AR) at $-70^{\circ} \mathrm{C}$ in a cassette with intensifying screens.

\section{Northern blots}

RNA samples (usually $2-4 \mu \mathrm{g}$ ) in $2.25 \mu \mathrm{l}$ were added to denaturing solution ( $2 \mathrm{ml} 5 \times$ running buffer, $3.5 \mathrm{ml}$ formaldehyde, $10 \mathrm{ml}$ formamide) to a total volume of $10 \mu \mathrm{l}$, and denatured by heating to $55^{\circ} \mathrm{C}$ for $15 \mathrm{~min}$. The RNA samples were separated by electrophoresis in $1 \%$ agarose gel with formaldehyde (Maniatis et al., 1982).

After electrophoresis, the gel was soaked at room temperature for $5 \mathrm{~min}$ in several changes of water, for $30 \mathrm{~min}$ in $50 \mathrm{mM} \mathrm{NaOH} / 10 \mathrm{mM} \mathrm{NaCl}$, for $30 \mathrm{~min}$ in $0.1 \mathrm{M}$ tris $-\mathrm{Cl}(\mathrm{pH} 7.5)$, and for $45 \mathrm{~min}$ in $20 \times \mathrm{SSC}$. The prepared gel was then placed on a nitrocellulose filter (Schleicher and Schuell, Keene, N.H., U.S.A.), soaked in $2 \times \mathrm{SSC}$, and covered with 3 pieces of $3 \mathrm{MM}$ paper soaked in $20 \times$ SSC. A glass plate and a $500 \mathrm{~g}$ weight were set on top and the entire assembly was left overnight. After the transfer was complete, the filter was washed in $3 \times \mathrm{SSC}$, air dried, and baked for $3-4 \mathrm{~h}$ at $80^{\circ} \mathrm{C}$ under vacuum to fix the RNA to the filter.

\section{RNA dot blots}

RNA samples, combined $1: 3$ with $6.15 \mathrm{M}$ formaldehyde $/ 10 \times \mathrm{SSC}$ and denatured by heating to $55^{\circ} \mathrm{C}$ for $15 \mathrm{~min}$, were spotted using a Minifold I (Schleicher and Schuell, Keene, N.H., U.S.A.) as a guide. The filters were placed under a lamp until dry, then baked for $2 \mathrm{~h}$ at $80^{\circ} \mathrm{C}$ under vacuum. Dot blots were hybridized with ${ }^{32} \mathrm{P}$-labelled amylase cDNA probe overnight, washed and air dried as described above. The dots were cut out and their radioactivity determined by scintillation counting.

\section{RESULTS}

A single injection of the high dose of isoproterenol $(8 \mathrm{mg} / \mathrm{kg})$ induced, as expected, a near total discharge of secretory proteins from the glands, and a significant increase in the rate of subsequent protein synthesis. The amylase content was reduced by about $97 \%$ of the unstimulated level in $2 \mathrm{~h}$, and it then increased gradually, reaching about $50 \%$ of the unstimulated

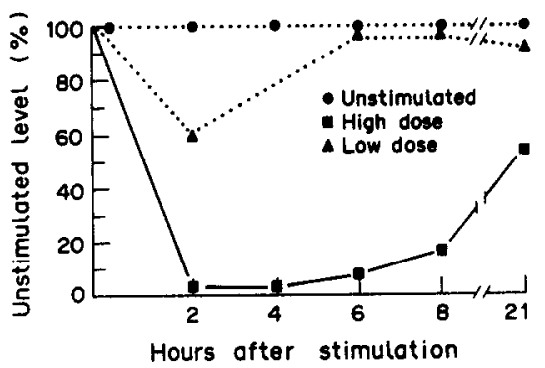

Fig. 1. Amylase content of rat parotid glands at various times after stimulation with an injection of high $(8 \mathrm{mg} / \mathrm{kg}$ body weight) and low $(0.4 \mathrm{mg} / \mathrm{kg}$ body weight) doses of isoproterenol. The enzyme activity, determined at each point, is shown as the percentage of the unstimulated level.

level in $21 \mathrm{~h}$ (Text Fig. 1). The amylase content was only about $7.6 \%$ of the unstimulated level at $6 \mathrm{~h}$ after injection. At this time, the rate of protein synthesis, as determined by the rate of incorporation of $\left[{ }^{3} \mathrm{H}\right]$-leucine into the acid-insoluble fraction, was elevated by about 2.6 times over the unstimulated level (Table 1).

In contrast, the lower dose of isoproterenol decreased the amount of discharge of stored secretory proteins (Text Fig. 1). Two hours after stimulation with isoproterenol $(0.4 \mathrm{mg} / \mathrm{kg}$ body weight $)$, the amylase content was reduced by only about $40 \%$ of the unstimulated level. The content was restored to almost the unstimulated level (about 97\%) $6 \mathrm{~h}$ after injection (Text Fig. 1).

Despite this small amount of secretion, the rate of post-secretory protein synthesis increased by about the same extent as in rats stimulated with the higher dose. The rate of incorporation of $\left[{ }^{3} \mathrm{H}\right]$-leucine into the glandular protein increased by about 2.5 times over the unstimulated level at $6 \mathrm{~h}$ after low-dose stimulation (Table 1). The rate of label incorporation $2 \mathrm{~h}$ after this low dose did not increase significantly above the unstimulated level (Table 1), as was the case after high-dose stimulation (Lillie and Han, 1973). The rate of incorporation of $\left[{ }^{3} \mathrm{H}\right]$-leucine into amylase (precipitated with glycogen) was increased by 4.33 and 3.85 times the unstimulated level in glands

Table 1. Rate of $\left[{ }^{3} \mathrm{H}\right]$-leucine incorporation into total and amylase proteins in parotid glands of isoproterenol-stimulated and unstimulated rats

\begin{tabular}{lcc}
\hline $\begin{array}{l}\text { Isoproterenol } \\
\text { stimulation }\end{array}$ & $\begin{array}{c}\text { Total protein } \\
(\text { acid-insoluble }) \\
\left(\text { dis } / \mathrm{min} \times 10^{2} / \mathrm{h}\right)\end{array}$ & $\begin{array}{c}\text { Amylase } \\
(\text { glycogen precip. }) \\
\left(\text { dis } / \mathrm{min} \times 10^{-2} / \mathrm{h}\right)\end{array}$ \\
\hline Unstimulated & $23.22 \pm 3.15$ & $1.51 \pm 0.23$ \\
High dose & $56.27 \pm 9.42$ & $5.82 \pm 0.19$ \\
$\quad(6 \mathrm{~h})$ & $(p<0.05)^{*}$ & $(p<0.001)^{*}$ \\
Low dose & $17.01 \pm 3.28$ & $2.13 \pm 0.42$ \\
$\quad(2 \mathrm{~h})$ & $(p>0.1)^{*}$ & $(p>0.05)^{*}$ \\
Low dose & $54.11 \pm 4.64$ & $6.54 \pm 0.79$ \\
$(6 \mathrm{~h})$ & $(p<0.001)^{*}$ & $(p<0.001)^{*}$ \\
\hline
\end{tabular}

Numbers are mean values of dis/min per mg DNA per $h$ and standard errors of means from three separate assays. Each incorporation value has been adjusted by the specific activity of the precursor pool (see text).

* Statistical significance of each value as compared to the unstimulated value in this column. 
$6 \mathrm{~h}$ after stimulation with high and low doses of isoproterenol, respectively (Table 1).

To determine whether levels of secretory protein messenger RNA change after stimulated secretion, we identified and quantified amylase messenger RNA with the amylase cDNA probe labelled with ${ }^{32} \mathrm{P}$. The parotid mRNA that hybridized with the radioactive amylase cDNA in Northern blots at various times after the stimulation with high and low doses of isoproterenol was of the same molecular size as the mRNA in unstimulated glands (Plate rig. 2).

The hybridization of the ${ }^{32} \mathrm{P}$-labelled probe increased linearly with increasing concentrations of amylase cDNA and antisense mRNA (Plate Fig. 3). In the presence of saturating probe concentrations, the amylase cDNA hybridized with parotid mRNA in a concentration-dependent manner in dot blots (Plate Fig. 4). The content of amylase mRNA in both stimulated groups was slightly higher than in unstimulated rats (Table 2). The increase in the mRNA content in both stimulated groups was statistically significant, although it was much less than the increase in the rate of protein synthesis measured by radioactive leucine incorporation. The amount of amylase mRNA increased by about 1.4 and 1.26 times the unstimulated level $6 \mathrm{~h}$ after stimulation with the high and low dose of isoproterenol, respectively.

\section{DISCUSSION}

A single injection of isoproterenol $(8 \mathrm{mg} / \mathrm{kg}$ ) induced the discharge of almost all stored proteins from the rat parotid gland, as was expected from the study of Lillie and Han (1973). Also, the rate of protein synthesis increased by about 2.5 times the unstimulated level $6 \mathrm{~h}$ after the injection. Stimulation with a much smaller dose $(0.4 \mathrm{mg} / \mathrm{kg})$ of isoproterenol induced the secretion of only $40 \%$ of the glandular protein. Despite this difference in protein secretion, rates of post-secretory synthesis of total protein, as well as of amylase, increased by about the same extent in the two groups. Thus, it appears that the rate of post-secretory protein synthesis increases to its maximum level after the discharge of at least $40 \%$ of stored proteins in this gland; the rate is therefore not regulated by any differences in amounts of secretory protein discharged.

It is not known what cellular factors or events are involved in raising the rate of secretory protein synthesis after stimulated secretion. As secretogogue effects on the rat parotid gland are mediated by cyclic AMP (Babad et al., 1967; Bdolah and Schramm,
1965; Malamud, 1972), cAMP might be involved in the stimulation of protein synthesis. However, an elevated cAMP level is maintained for only about $45 \mathrm{~min}$ in parotid glands after a single injection of isoproterenol (Furono, Asami and Matsudaira, 1974), whereas the peak of protein synthesis is not reached until $6 \mathrm{~h}$. Thus, it is unlikely that the sustained high level of protein synthesis requires the presence of CAMP, although some early events preceding the process of protein synthesis might be cAMP-dependent.

Regardless of how the rate of secretory protein synthesis increases after stimulated discharge, it was expected that this increase would be accompanied by a parallel increase in the available amount of mRNA for these proteins. The rate of synthesis of a protein is generally proportional to the available amount of its corresponding mRNA, and the degree of mRNA stability plays an important role in the regulation of protein synthesis (Lodish, 1976). In developing pancreas (Harding and Rutter, 1978; Przybyla et al., 1979) and the parotid gland (Poulsen et al., 1986; Shaw, Sordat and Schibler, 1986), the rate of amylase synthesis is related to the rate of accumulation of amylase mRNA.

We found small but significant increases in the available amounts of amylase mRNA in isoproterenol-stimulated glands. The mRNAs present at various times after stimulation were of one molecular size, the same size as in unstimulated glands (Plate Fig. 2). Thus it is likely that the increase in the amount of the mRNA represents the synthesis of functionally mature amylase mRNA after stimulated secretion. However, the magnitude of the increases in amylase mRNA in either dosage group did not parallel that of the increases in rates of synthesis of total or amylase proteins.

One possible explanation for this discrepancy is an increase in the rate of amylase mRNA degradation, which would prevent mRNA accumulation in the gland after stimulated secretion. Apparently, the rate of degradation of some species of mRNA changes in response to physiological stresses, such as hormone induction in animals (Guyette, Matusik and Rosen, 1979; Brock and Shapiro, 1983), or alterations in growth rate in bacteria (Nilsson et al., 1984).

Alternatively, it is possible that the mRNA available in stimulated glands is much more efficient in its translational activity than its counterpart in unstimulated glands. Modifications, such as cap and cap-methylation at the $5^{\prime}$ terminus, have been shown to increase mRNA translatability (Kozak, 1980;

Table 2. Amylase messenger RNA content in parotid gland before and after stimulation with high and low doses of isoproterenol

\begin{tabular}{ccc}
\hline $\begin{array}{c}\text { Hours after } \\
\text { stimulation }\end{array}$ & \multicolumn{1}{c}{$\begin{array}{l}\text { High dose } \\
\left.\text { (dis/min per } \mu \mathrm{g} \mathrm{RNA} \times 10^{-3} \pm \mathrm{SEM}\right)\end{array}$} \\
\hline Unstimulated & \multicolumn{2}{c}{$43.64 \pm 1.90$} \\
1 & $53.58 \pm 0.73^{*}(1.23 \times \mathrm{C})$ & $45.61 \pm 7.25(1.05 \times \mathrm{C})$ \\
2 & $51.73 \pm 3.64(1.19 \times \mathrm{C})$ & $46.85 \pm 5.16(1.07 \times \mathrm{C})$ \\
4 & $51.90 \pm 1.97^{*}(1.19 \times \mathrm{C})$ & $55.64 \pm 4.30^{*}(1.27 \times \mathrm{C})$ \\
6 & $60.99 \pm 3.55^{*}(1.40 \times \mathrm{C})$ & $54.91 \pm 6.23^{*}(1.26 \times \mathrm{C})$ \\
\hline
\end{tabular}

Each value is the mean \pm SEM from 8 determinations; each group consisted of 4 rats. The values marked with * are those which are statistically $(p<0.05)$ different from the unstimulated value. Numbers in parentheses are the ratio: stimulated value/control value. 
Cordell et al., 1982). Some portions of secretory protein mRNA in unstimulated glands might also be sequestered in the cytoplasm, inaccessible to ribosomes for translation. The secretogogue-stimulated phosphorylation of a 29 kdalton polypeptide, an integral protein of ribosomal S6 in the pancreas and parotid gland (Freedman and Jamieson, 1982a,b,c), might increase the accessibility of ribosomes to secretory protein mRNAs. Furthermore, this kind of peptide can also indirectly stimulate mRNA translational activity by modulating the activity of other peptides, such as the cap-binding protein (Cordell et al., 1982). These possibilities imply the translational control of secretory protein synthesis.

It is therefore, possible that the synthesis of amylase in rat parotid gland, after stimulated secretion is regulated at the level of translation. In fact, Grand and Gross (1970) have reported that the addition of actinomycin D 30 min before stimulation of parotid glands by epinephrine does not prevent amylase release or the subsequent increase in amylase and total protein synthesis. They concluded that the control of amylase synthesis was exerted at the translation level, independent of transcription. There are many examples of the translational control of protein synthesis (Cordell et al., 1982; Noe, 1981; Thireos, Griffin-Shea and Kafatos, 1980; Lindquist, 1981).

It will now be necessary to measure the rates of transcription and degradation of parotid secretory protein mRNAs, and their translational efficiency, in order to determine whether the stimulated synthesis of secretory proteins is indeed regulated at the translational level.

Acknowledgements-We thank Dr Miriam H. Meisler of the Department of Human Genetics at the University of Michigan Medical School for providing us with amylase complementary DNA. This work was supported in part by the Veterans Administration and by NIH grants DE08109 and AG07159.

\section{REFERENCES}

Amsterdam A., Ohad I. and Schramm M. (1969) Dynamic changes in the ultrastructure of the acinar cell of the rat parotid gland during the secretory cycle. J. Cell Biol. 41, 753-773.

Babad S., Ben-Zvi S. R., Bdolah A. and Schramm M. (1967) The mechanism of enzyme secretion by the cell. 4 . Effects of inducers, substrates and inhibitors of amylase secretion by rat parotid slices. Eur. J. Biochem. 1, 96-101.

Bdolah A. and Schramm M. (1965) The function of 3'5' cyclic AMP in enzyme secretion by the cell. Biochem. biophys. Res. Commun. 18, 452-454.

Bernfeld P. (1955) Amylases, alpha and beta. Meth. Enzymol. 1, 149-158.

Bohlen P. and Mellet M. (1979) Automated fluorometric amino acid analysis: the determination of proline and hydroxyproline. Analyt. Biochem. 94, 313-321.

Brock M. L. and Shapiro D. J. (1983) Estrogen stabilizes vitellogenin mRNA against cytoplasmic degradation. Cell 34, 207-214.

Burton K. (1956) A study of the conditions and mechanism of the diphenylamine reaction for the colorimetric estimation of deoxyribonucleic acid. Biochem. J. 62, 315-323.

Castle J. D., Jamieson J. D. and Palade G. E. (1972) Radioautographic analyses of the secretory process in the parotid acinar cell of the rabbit. J. Cell Biol. 53, 290-311.
Chirgwin J. M., Pryzybyla A. E., MacDonald R. J. and Rutter W. J. (1979) Isolation of biologically active ribonucleic acid from sources enriched in ribonuclease. Biochemistry 18, 5294-5299.

Cordell B., Diamond D., Smith S., Punter J., Schone H. H. and Goodman H. M. (1982) Disproportionate expression of the two nonallelic rat insulin genes in a pancreatic tumor is due to translational control. Cell 31, 531-542.

Feinberg A. P. and Vogelstein B. (1983) A technique for radiolabeling DNA restriction endonuclease fragments to high specific activity. Analyt. Biochem. 132, 6-13.

Freedman S. D. and Jamieson J. D. (1982a) Hormoneinduced protein phosphorylation. I. Relationship between secretagogue action and endogenous protein phosphorylation in intact cells from the exocrine pancreas and parotid. J. Cell Biol. 95, 903-908.

Freedman S. D. and Jamieson J. D. (1982b) Hormone induced protein phosphorylation. II. Localization to ribosomal fraction from the rat exocrine pancreas and parotid of a 29,000-dalton protein phosphorylated in situ in response to secretagogues. J. Cell Biol. 95, 909-917.

Freedman S. D. and Jamieson J. D. (1982c) Hormoneinduced protein phosphorylation. III. Regulation of the phosphorylation of the secretogogue-responsive 29,000 dalton protein by both $\mathrm{Ca}^{2+}$ and CAMP in vitro. J. Cell Biol. 95, 918-923.

Furono L., Asami K. and Matsudaira H. (1974) Inhibition by $\mathrm{X}$-irradiation and antimetabolites of DNA synthesis without affecting cAMP elevation in isoproterenolstimulated mouse parotid gland. Expl. Cell Res. 89, 47-54.

Grand R. J. and Gross P. R. (1970) Translation-level control of amylase and protein synthesis by epinephrine. Proc. natn. Acad. Sci. U.S.A. 65, 1081-1088.

Guyette W. A., Mutusik R. J. and Rosen J. M. (1979) Prolactin-mediated transcriptional and post-transcriptional control of casein gene expression. Cell 17, 1013-1023

Harding J. D. and Rutter W. J. (1978) Rat pancreatic amylase mRNA, tissue specificity and accumulation during embryonic development. J. biol. Chem. 253, 8736-8740.

Johnson D. A. and Sreebny L. M. (1973) Effect of increased mastication on the secretory process of the rat parotid gland. Archs oral Biol. 18, 1555-1558.

Jonas A. M., Craft J., Black C. L., Bhatt P. N. and Hilding D. (1969) Sialodacryoadenitis in the rat. A light and electron microscopic study. Archs Path. 88, 613-622.

Kim S. K. (1981) Age-related changes in the cellular level of amylase and protein synthesis in the rat parotid gland. J. dent. Res. 60, 738-749.

Kim S. K. and Arisumi P. P. (1985) The synthesis of amylase in parotid glands of young and old rats. Mech. Aging Devl. 31, 257-266.

Kim S. K., Weinhold P. A., Han S. S. and Wagner D. J. (1980) Age-related decline in protein synthesis in the rat parotid gland. Expl Geront. 15, 71-85.

Kim S. K., Weinhold P. A., Calkins D. W. and Hartog V. W. (1981) Comparative studies of the age-related changes in protein synthesis in the rat pancreas and parotid gland. Expl Geront. 16, 91-100.

Kozak M. (1980) Evolution of the "scanning model" for initiation of protein synthesis in eucaryotes. Cell 22, $7-8$.

Lillie J. H. and Han S. S. (1973) Secretory protein synthesis in the stimulated rat parotid gland. Temporal dissociation of the maximal response from secretion. J. Cell Biol. 59, 708-721.

Lindquist S. (1981) Regulation of protein synthesis during heat shock. Nature 293, 311-314.

Lodish H. F. (1976) Translational control of protein synthesis. A. Rev. Biochem. 45, 39-72.

Loyter A. and Schramm M. (1962) The glycogen-amylase 
complex as a means of obtaining highly purified $\alpha$ amylases. Biochim. biophys. Acta 65, 201-206.

Malamud D. (1972) Amylase secretion from mouse parotid and pancreas: role of cyclic AMP and isoproterenol. Biochim. biophys. Acta 279, 373-376.

Maniatis T., Fritsch E. F. and Sanibrook J. (1982) Molecular Cloning, A Laboratory Manual. Cold Spring Harbour Lab., New York.

Nilsson G., Belasco J. G., Cohen S. N. and Gabain A. von (1984) Growth-rate dependent regulation of mRNA stability in Escherichia coli. Nature 312, 75-77.

Noe B. D. (1981) Synthesis of one form of pancreatic istet somatostatin predominates. J. biol. Chem. 256, 9397-9400.

Palade G. E. (1975) Intracellular aspects of the process of protein synthesis. Science 189, 347-358.

Poulsen K., Jakobsen B. K., Mikkelsen B. M., Harmark K., Nielsen J. T. and Hiorth J. P. (1986) Coordination of murine parotid secretory protein and salivary amylase expression. EMBO J. 5, 1891-1896.

Przybyla A. E., MacDonald R. J., Harding J. D., Pictet R. L. and Rutter W. J. (1979) Accumulation of the predominant pancreatic mRNA during embryonic development. J. biol. Chem. 254, 2154-2159.

Shaw P., Sordat B. and Schibler U. (1986) Developmental coordination of $\alpha$-amylase and Psp gene expression during mouse parotid gland differentiation is controlled posttranscriptionally. Cell 47, 107-112.

Sreebny L. M., Johnson D. A. and Robinovitch M. R (1971) Functional regulation of protein synthesis in the rat parotid gland. J. biol. Chem. 246, 3879-3884.

Thireos G., Griffin-Shea R. and Kafatos F. C. (1980) Untranslated mRNA for a chorion protein of Drosophila melanogaster accumulates transiently at the onset of specific gene amplification. Proc. natn. Acad. Sci. U.S.A. 77, 5789-5793.

Plate 1

Fig. 2. Northern blot analyses of amylase mRNA in rat parotid glands, either unstimulated or stimulated with isoproterenol. Two microgrammes of total parotid RNA were loaded in each lane of agarose gel and RNA was transferred overnight on to a nitrocellulose filter. Lanes 1,6 and 11 contained total parotid RNA from unstimulated rats. Lanes 2, 3, 4 and 5 contained total parotid RNA from rats stimulated with the high dose of isoproterenol, 1, 2, 4 and $6 \mathrm{~h}$ after the injection, respectively. Lanes $7,8,9$ and 10 contain RNA from rats stimulated with the low dose of isoproterenol and killed $1,2,4$ and $6 \mathrm{~h}$ after the injection, respectively.

Fig. 3. Dot blot hybridization of the ${ }^{32} \mathrm{P}$-labelled amylase cDNA probe with $0.5,1,2,4$ and $8 \mathrm{ng}$ of amylase cDNA (A) and antisense mRNA (B), which was generated by the Riboprobe system (Promega Biotech, Madison, Wis., U.S.A.) with the amylase $\mathrm{cDNA}$ as the template. The hybridization signal increases linearly with increasing concentrations of amylase cDNA and mRNA.

Fig. 4. Dot blot hybridization of ${ }^{32} \mathrm{P}$-labelled amylase cDNA with increasing concentrations $(0,25,50$, 75 and $100 \mathrm{ng}$ ) of total unfractionated RNA from parotid glands of stimulated and unstimulated (U) rats. The stimulated parotid RNA samples were obtained $1,2,4$ and $6 \mathrm{~h}$ after injection of high dose $(8 \mathrm{mg} / \mathrm{kg}$ body weight) of isoproterenol. 


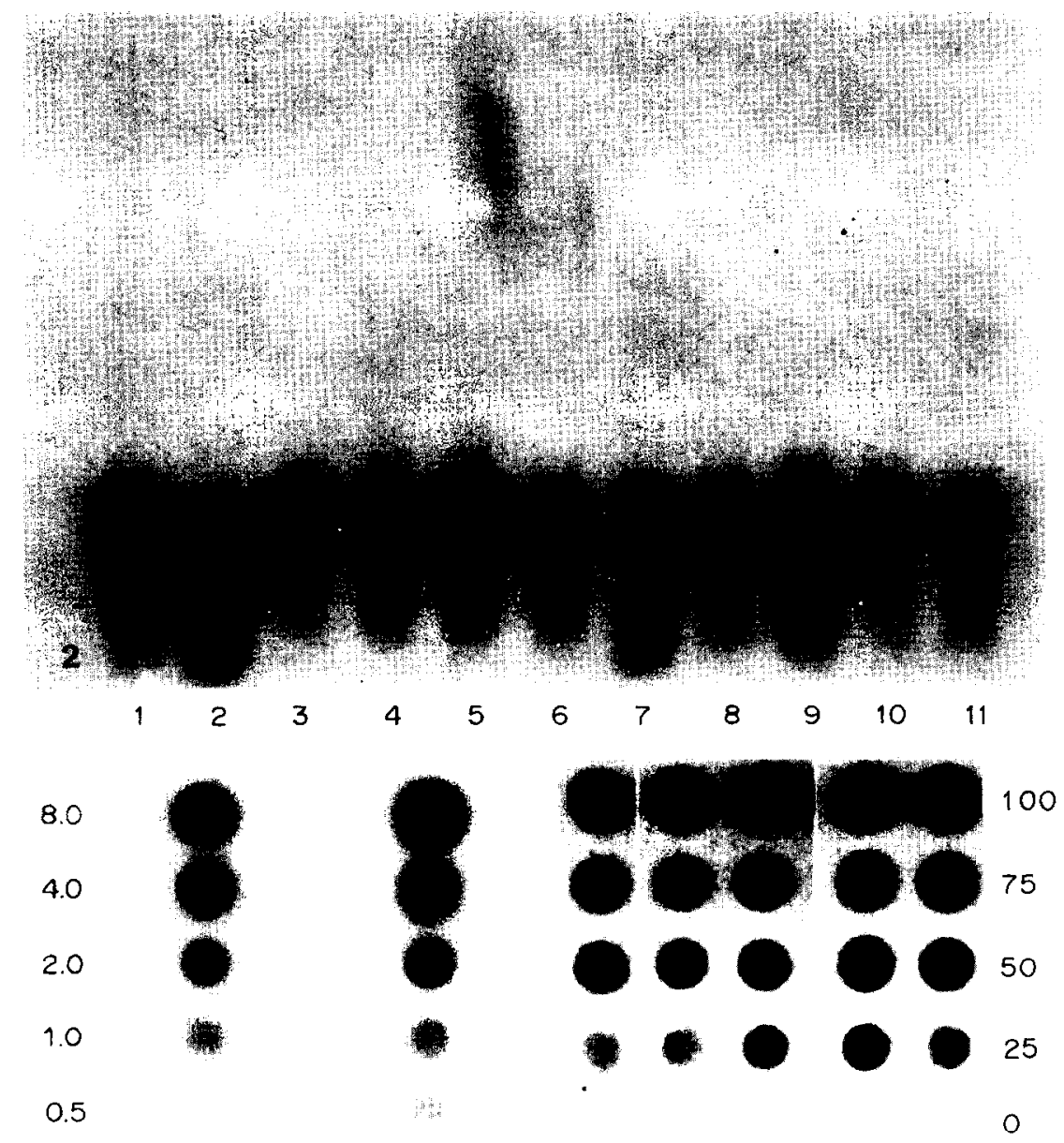

$3 A$

B

$4 \mathrm{U}$

2

4

6

Plate 1 